[Vol. 129:1392

\title{
COMMENTS
}

\section{THE RADICAL POTENTIAL OF THE WAGNER ACT: THE DUTY TO BARGAIN COLLEGTIVELY}

Recent works of American legal history have attempted to explain the evolution of law not only as the internal development of a set of rules, but also as a reflection of, and influence on, changes within society. ${ }^{1}$ Karl Klare's ${ }^{2} 1978$ article entitled Judicial Deradicalization of the Wagner Act and the Origins of Modern Legal Consciousness, $1937-1941^{3}$ is an example of such scholarship. Klare examines the passage of the Wagner Act ${ }^{4}$ by Congress, and its interpretation in Supreme Court decisions of the late 1930s. ${ }^{5}$ His central thesis is that the terms and goals of the Act were open to an interpretation that would have radically restructured the American workplace, and with it "the premises and institutions of capitalist society." - Instead, "the [Supreme] Court embraced those aims of the Act most consistent with the assumptions of liberal capitalism and foreclosed those potential paths of development most threatening to the established order." 7 Klare argues that the Court's decisions thus destroyed the radical potential of the Wagner Act and laid the intellectual foundations for "the deradicalization and incorporation of the working class." 8

I See, e.g., L. Friedman, A Hrstory of AMERrcan LAW (1973); M. Horwitz, The Transformation of American Law 1780-1860 (1977).

2 Professor of Law, Northeastern University.

3 Klare, Judicial Deradicalization of the Wagner Act and the Origins of Modern Legal Consciousness, 62 MrNN. L. REv. 265 (1978).

4 National Labor Relations Act (NLRA or Wagner Act), ch. 372, 49 Stat. 449 (1935) (current version at 29 U.S.C. $\$ \$ 151-168$ (1976)). The NLRA was substantially amended by the Labor Management Relations (Taft-Hartley) Act, ch. 120, 61 Stat. 136 (1947) (current version at 29 U.S.C. $\$ \$ 141-187$ (1976)), and by the Labor-Management Reporting and Disclosure (Landrum-Griffin) Act of 1959, Pub. L. No. 86-257, 73 Stat. 519 (codified in scattered sections of 29 U.S.C.).

5 Klare discusses Phelps Dodge Corp. v. NLRB, 313 U.S. 177 (1941); Pittsburgh Plate Glass Co. v. NLRB, 313 U.S. 146 (1941); H.J. Heinz Co. v. NLRB, 311 U.S. 514 (1941); NLRB v. Sands Mfg. Co., 306 U.S. 332 (1939); NLRB v. Fansteel Metallurgical Corp., 306 U.S. 240 (1939); NLRB v. Mackay Radio \& Tel. Co., 304 U.S. 333 (1938), and NLRB v. Jones \& Laughlin Steel Corp., 301 U.S. 1 (1937).

6 Klare, supra note 3 , at 267.

7 Id. 292.

8Id. 268. Klare never expressly defines what he means by "radical" and "deradicalization." He does define " incorporation' or "integration' of the working class" as referring to:

[T] he complex historical transition from a prototypical mode of workingclass self-consciousness (reflected in its institutions and struggles), in which 
This Comment examines one of the historical claims Klare makes in support of his argument that the meaning of section $8(5)^{9}$ of the Wagner Act-setting forth the employer's duty "to bargain collectively with the representatives of his employees" 10 -was unclear when the Act was passed. He argues that it would have been fair to the terms of the Act, the legislative history, and the political climate of the times to interpret the provision as empowering the National Labor Relations Board (NLRB or Board) and the courts to review the substantive terms of an employer's offer. ${ }^{11}$ Under this interpretation of section 8(5), an employer would be guilty of an unfair labor practice if his offer did not conform to an objective standard of reasonableness. Such an employer would be subject to remedies fashioned by the NLRB to "effectuate the policies of this Act." 12 These remedies, according to Klare, could have included compulsory arbitration. ${ }^{13}$

Klare argues that adoption of the substantive model of review would have had radical results. Because the substantive-review model rejects freedom of contract as the touchstone of labor relations, its adoption would have provoked, according to Klare, a crisis in liberal political theory. ${ }^{14}$ Moreover, substantive review would have drawn the attention of the courts, the working class, and the general public to the fairness of the wage bargain, with a politicizing

the working class saw itself as outcast, lacking entitlement to participation as of right in the affairs of state, and forced by hostile social and political institutions to depend entirely on its own efforts to secure economic and social betterment, to one in which it sees itself as having claims upon the state, interests that are in part synonymous with those of the state, and meaningful participation in the state's affairs. Paralleling this transformation is a process by which the earlier understanding of key political actors that relations between capital and labor were essentially private transactions is transformed into a perception that the adjustment of relations between capital and labor is, to a significant degree, a concern of public policy.

This incorporation process is assumed to have a deradicalizing impact on working-class movements. 'Incorporation' imports more than mere concessions by the established order; it connotes a change in the self-conception of the working class.

Id. $267-68$ n.10.

929 U.S.C. $\$ 158(a)(5)$ (1976). Section $8(5)$ makes it an unfair labor practice for an employer "to refuse to bargain collectively with the representatives of his employees, subject to the provisions of section 9(a)." Section 9(a), 29 U.S.C. $\$ 159$ (a) (1976), requires that an employer bargain with the representative selected by a majority of the employees in a bargaining unit.

1029 U.S.C. $\$ 158(\mathrm{a})(5)(1976)$.

11 See Klare, supra note 3, at 284-92 \& nn.62 \& 73, 307-08 \& n.145.

1229 U.S.C. $\$ 160$ (c) (1976).

13 Klare, supra note 3 , at 288.

14 Id. $295 \mathrm{n} .91$. 
and destabilizing effect on the labor movement. ${ }^{15}$ The Court instead chose to interpret the duty to bargain collectively as requiring only that employers negotiate with labor representatives, not that they offer reasonable terms. ${ }^{16}$ By this interpretation, Klare argues, the Court revitalized the ideology of freedom of contract, ${ }^{17}$ and "deradicalized" the potential of the Wagner Act."18

Klare thus maintains that the Supreme Court decided between two plausible alternatives when it interpreted the Wagner Act as erecting a procedural rather than a substantive model of review. This Comment evaluates his claim in its historical context, and concludes that Klare fails to prove his contention.

The Supreme Court was faced with the task of interpreting a provision whose terms were vague and whose legislative history could arguably be described as ambiguous. ${ }^{19}$ In such a situation, the Court might properly seek guidance by examining the political context that produced the Wagner Act. If it were to do so, however, the Court would find a remarkable consensus against substantive review among supporters and opponents of the bill. ${ }^{20}$ In the face of this consensus, for the Supreme Court to have interpreted section $8(5)$ in accordance with Klare's "plausible" alternative would have been "radical" indeed, and, moreover, highly improper. The Court, therefore, did not "deradicalize" this provision of the Wagner Act; rather, it remained true to the reformist impulses that prompted its passage.

Part I of this Comment summarizes Klare's argument that the terms and premises of section $8(5)$ had a radical potential that was declawed by the Supreme Court. Part II examines the relevant legislative history. Part III looks at the attitudes towards substantive review of a variety of groups supporting and opposing passage of the Act. Finding virtually no support for substantive review in the legislative history, and that legal scholars and business, labor, and radical groups all opposed the interpretation of section 8(5) that Klare claims was a viable alternative, the Comment concludes that the historical evidence on this issue does not support Klare's revisionist perspective.

15 Id. 309 n.151. (1937)).

${ }^{16}$ See id. 298 (discussion of NLRB v. Jones \& Laughlin Steel Corp., 301 U.S. 1

17 See Klare, supra note 3, at 306-10.

$18 \mathrm{Id} .309 \mathrm{n} .15 \mathrm{l}$.

19 See notes 26-29 infra \& accompanying text.

20 See text accompanying notes 102-92 infra. 
I. Krare's Argument: The Radical Potential of the Wagner Act and the Scope of the Duty to Bargatn

Karl Klare argues that the Wagner Act, when passed, "was perhaps the most radical piece of legislation ever enacted by the United States Congress." ${ }^{21}$ To support this characterization, Klare points to both the political climate of the times and the text and legislative history of the Act. The Wagner Act, according to Klare, was passed "in the wake of the great strikes of 1934, at an unusually tense and fluid historical moment." 22 Its passage engendered bitter opposition from the business community, ${ }^{23}$ and the strong support of organized labor. ${ }^{24}$ Meanwhile, working people, perhaps contemplating that the Act could lead to a "radical restructuring of relationships within the workplace . . . [,] fought with determination to make the Act a reality." 25

Klare submits that "[t]he Act's plain language was susceptible to an overtly anticapitalist interpretation," although he acknowledges that the legislative history does not necessitate such a reading. ${ }^{20} \mathrm{He}$ views provisions of the legislation, especially in the findings and declarations of policy, as possibly indicating an intent to give labor organizations bargaining power equal to that of managers of large corporations, to facilitate worker participation in industrial governance, and to provide increased economic benefits for workers, thus accomplishing a redistribution of income. ${ }^{27}$ The legislative history of the Act, Klare argues, did not preclude this radical interpretation; rather, the legislature was silent, or at best inconclusive, about the meaning of most of the key terms and phrases of the bill. ${ }^{28}$ At the very least, Klare contends, there existed no agreed-upon set of ideas or principles by which to interpret the statute conclusively. ${ }^{29}$

Under these circumstances, it was left for the new NLRB, and ultimately the Supreme Court, to interpret the Act's broad-based provisions. The Court was forced to guide the nation's new labor

21 Klare, supra note 3, at 265.

22 Id.

23 Id. 285-89. For a discussion of the views of the business community, see text accompanying notes 128-36 infra.

24 See notes 114-27 infra \& accompanying text.

25 Klare, supra note 3, at 290.

26 Id. $285 \& \mathrm{n} .62$.

27 Id. 285.

28 Id. 281,285 n. 62 .

29 Id. 291. 
policy, however, in the midst of its own intellectual revolution. The Court was under the well-documented political attack of the legislative and political branches for striking down New Deal legislation for violating due process or commerce clause limitations. ${ }^{30}$ More broadly, the conceptualism ${ }^{31}$ that marked judicial decisionmaking during the Lochner ${ }^{32}$ era left the Court vulnerable to the intellectual attack of the realists. ${ }^{33}$ The realists exposed the controversial value judgments inherent in the Court's purportedly neutral decisionmaking process and denied that neutrality was a possible or desirable objective, suggesting instead that instrumentalism-reasoning from ends to means-was more proper and just. ${ }^{34}$

By 1937, realist jurisprudence had gained ascendency on the bench as well as in academic circles. Yet realism, if carried to its logical end, threatened to destroy the sanctified position of law in liberal political theory. ${ }^{35}$ If all legal decisionmaking were reduced to a political battle over social goals, the notion of law standing above the particular configuration of political power would have to be abandoned. In such circumstances, the exercise of judicial power by unelected judges would come to be viewed as tyranny. ${ }^{36}$

Klare thus suggests that the early Wagner Act decisions marked a "traumatic encounter" ${ }^{37}$ on both intellectual and political levels between the status quo and forces of change. The reaction of the Supreme Court was to bow to the progress of history and declare the Act constitutional. ${ }^{38}$ Klare, however, views the Supreme Court's

30 See, e.g., G. Gunther, Cases and Materinis on Constrtuttonat Law 150-52 (10th ed. 1980); L. Trube, Amerucan Constitutional Law 446-49 (1978).

81 "Conceptualism" is the term Klare uses to describe "a particular version of formalism that was the prevailing mode of thought among the legal elite in the United States in the period roughly from 1885 to $1930 . "$ Klare, supra note 3 , at 278. "Formalism" refers to "styles of legal reasoning that assume that the processes of deriving legal rules to govern new situations and of applying ascertained rules to. given sets of facts can be relatively determinate, objective, and value-free operations." Id. 277-78. "The characteristic conceptualistic glosses to formalism are the belief that very abstract and general principles of law can be used to resolve very concrete legal problems and an identification of legal reasoning with natural science." Id. 278.

32 Lochner v. New York, 198 U.S. 45 (1905). Lochner has come to symbolize the method of legal analysis described by Klare as conceptualism. See Klare, supra note 3 , at 278 n. 44 .

${ }^{33}$ See Klare, supra note 3 , at 278-79. Realism is described by Klare as "a movement in legal thought that united thinkers of disparate political philosophies in an attack on conceptualism." Id. 278.

34 Id. 278-79.

35 See id. 279.

36 See generally R. UNGER, KNowhedge and Polrtics (1975).

37 Klare, supra note 3, at 279.

38 See NLRB v. Jones \& Laughlin Steel Corp., 301 U.S. 1 (1937). See also R. Cortner, The Jones \& Laugrind Case 169 (1970) ("[W] 
transformation as a triumph of form over substance, because the Court rescued the essential features of American capitalism from the threat of radical revision and at the same time grafted the language of realism onto the retained core of conceptualistic legal thought. ${ }^{39}$

One of the ways the Supreme Court accomplished this feat was to interpret the Wagner Act through the lens of contractualism. ${ }^{40}$ In NLRB v. Jones \& Laughlin Steel Corp., ${ }^{41}$ its first decision under the Act, the Court ensured that the wage bargain would remain a product of private ordering by holding that section $8(5)$-which made it an unfair labor practice for an employer to refuse to bargain collectively with representatives of his employees-did not empower the NLRB to compel labor agreements. ${ }^{42}$ The Court eschewed any role for the NLRB or the courts in reviewing the substance of the wage offer, interpreting the Act to require only that the employer sit down and negotiate with his employees' representatives, not that his offer be reasonable. The substance of the agreement would thus continue to be determined by the comparative economic strength of the parties.

Under the Court's interpretation of section $8(5)$, the NLRB undertakes only a procedural review of the good faith of the parties at the bargaining table. ${ }^{43}$ This result, Klare argues, was not necessitated by the terms or history of the Wagner Act, neither of which explicitly defined the role intended for the government in regulating negotiation of the collective agreement. "[A]s a matter of history, there was no clear national policy or consensus by 1935 indicating that private-ordering was always, or even ordinarily, the

political and social unrest beat upon the Court in the spring of 1937, [the Justices] did not feel bound to a rigid adherence to previous utterances in the hope of maintaining reputations for constitutional consistency.").

$39 \mathrm{Klare}$, supra note 3, at 279-80, 292.

Klare does not regard the Supreme Court's adaptation of traditional legal theory to the new economic reality as a conspiracy to defeat the radical movement in labor or in legal theory. He recognizes 'the 'relative autonomy' of legal consciousness." Id. 269 n.13. He notes the paradox that "Iaw ultimately reflects and sustains the social order, yet has its own internal logic and unique modes of discourse ... that are to some extent independent of the will of powerful, nonlegal, social and political actors.", Id.

40 "Contractualism" is Klare's term for the ideology of freedom of contract, with its central "moral ideal" that "justice consists in enforcing the agreement of the parties so long as they have capacity and have had a proper opportunity to bargain for terms satisfactory to each." Id. 285.

41301 U.S. 1 (1937).

42 "The Act does not compel agreements between employers and employees. It does not compel any agreement whatever." Id. 45.

43 See H.J. Heinz Co. v. NLRB, 311 U.S. 514, 525-26 (1941).

44 Klare, supra note 3, at 307-08. 
preferred method of government regulation of the wage bargain . . ." $4 \mathrm{5}$ Klare concludes that, "given that substantive scrutiny was at least a plausible outcome in light of the legislative history, . . . the Court's preference for purely procedural review represented a matter of conscious choice." 46

The Court's adoption of the procedural review model helped deradicalize the Wagner Act in three ways. First, in accordance with Marxist economic analysis, Klare regards any wage bargain resulting from private ordering as "inherently an unequal exchange": the value produced by the employee ordinarily must exceed the value he receives in wages, because surplus profit is reserved for the capitalist. ${ }^{47}$ Klare also notes that the wage contract cements the worker into an entire complex of social relationships: once viewed as a seller of his labor, the worker is forced to produce what the boss wants, to submit to the discipline that the boss imposes, and to do the work that is chosen for him. ${ }^{48}$ The Supreme Court's procedural interpretation of section $8(5)$, then, deradicalized the Act by crippling that provision's potential to further industrial democracy.

Second, the Court's articulation of the procedural review model represented " $[t]$ he rudimentary foundations of a new jurisprudential synthesis, 'social conceptualism." 49 The Court simultaneously embraced two apparently contradictory values-state regulation and private ordering-by affirming "that it is appropriate and just for the state to rearrange the relative bargaining strengths of capital and labor because the pre-existing disparity of power produced substantively unacceptable results and that the state ought not to intervene in private wage-bargaining to encourage or assure any particular substantive outcome." 50 Klare argues, in short, that social conceptualism met the realist attack by incorporating it, maintaining the illusion of judicial neutrality while accommodating ad hoc social goals. To the extent that workers allowed their self-consciousness to be defined by the Supreme Court, then, the formulation of the new legal consciousness aided in the incorporation of the working class. ${ }^{61}$

$451 d .288 \mathrm{n} .73$

46 Id. 308 (footnote omitted).

47 Id. 297 \& $\mathrm{n} .101$.

48 See id. 297.

49 Id. 309.

$50 \mathrm{Id}$.

61 See note 8 supra. 
Third, Klare claims that substantive scrutiny by the NLRB of the terms of the employer's wage offer would have introduced a potentially radicalizing force into law by making those terms a "public political issue." 52 This argument contains strands of the previous two. If the NLRB could determine that an offer was so low as to be unreasonable, it would adjudge the employer guilty of an unfair labor practice. Public attention would then become focused on what a fair wage rate would be. This process would, according to Klare, alert the working class to the inherent unfairness of the wage bargain, and expose the value-laden content of the allegedly neutral decisions of the government and the courts. Because it deflected attention away from the political issue implicit in wage negotiation, "the Court's preference for a formal, proceduralist model represented a deradicalization of the potential of the Wagner Act." 58

\section{Legislative History: Congressional Limitations on GOVERNMENT INTERVENTION}

Klare maintains that "substantive scrutiny was at least a plausible outcome in light of the legislative history." 54 He apparently ${ }^{55}$ bases this statement on a 1941 law review article by Professor Russell Smith, ${ }^{56}$ and on the undocumented assertion that "it was clear from the pre-NLRA experience of the National Labor Board and the 'old' National Labor Relations Board . . . that the duty to bargain would have to mean more, if it were to mean anything, than just a minimal duty physically to meet with employee representatives." 57 Klare also presents the views of business leaders as support for the argument that the Act could have been interpreted as imposing a system of compulsory arbitration. ${ }^{68}$

52 Klare, supra note 3 , at $309 \mathrm{n} .151$ (emphasis omitted).

53 Id.

Klare never explicitly acknowledges the tension lurking between his advocacy of substantive review and his commitment to worker self-activity. See id. 324-25. Making workers rely on government to grant them fair labor contracts, instead of forcing them to fight and win those victories themselves, might have had a depoliticizing effect on the labor movement. Evidence suggests that unions and radical groups opposed substantive review precisely because they recognized those implications. See notes 114-92 infra \& accompanying text.

54 Klare, supra note 3 , at 308 . article).

55 Klare's statement is not footnoted, but see id. $288 \mathrm{n} .73$ (discussion of Smith's

${ }^{5 B}$ Smith, The Evolution of the "Duty to Bargain" Concept in American Law, 39 Mick. L. REv. 1065 (1941).

67 Klare, supra note 3 , at 307.

68 Id. 285-89. For a discussion of the views of business leaders toward the Act and the scope of the duty to bargain they believed it imposed, see notes 128-36 infra \& accompanying text. 
This Comment argues that the evidence does not support Klare's conclusion. To assist in the discussion, four models of collective bargaining are presented, positing varying degrees of government-involvement in the wage bargain. An examination of the legislative history will demonstrate that Congress foreclosed the model of substantive scrutiny that Klare suggests was plausible. The Smith article, upon which Klare heavily relies, does not provide persuasive evidence to the contrary.

Since the legislative history indicates a congressional intention to limit the role of government in the wage bargain to some form of procedural scrutiny, Klare is incorrect in his assessment that the judiciary deradicalized this aspect of the Wagner Act. The Court simply followed the legislative intent. Perhaps Klare would continue to argue that the Court should have encouraged the NLRB to judge the reasonableness of the wage offer, because of the benefits to the working class that he envisions would result from such an interpretation. ${ }^{69}$ This moral claim, however, would be different from the historical claim Klare actually makes: that the Court could have interpreted section $8(5)$ as erecting a system of substantive scrutiny, while remaining within the traditional confines of statutory construction.

\section{A. Models of the Duty to Bargain Collectively}

Section $8(5)$ of the Wagner Act made it an unfair labor practice for an employer "to refuse to bargain collectively with the representatives of his employees." ${ }^{0}$ Neither the intended scope of the employer's duty to bargain collectively nor the NLRB's power to enforce it is immediately clear from the words of the statute. ${ }^{61}$ As the terms of section $8(5)$ are ambiguous, the duty to bargain must be assigned a special meaning in order to be made intelligible. At least four conceptually distinct understandings of the employer's duty and the NLRB's enforcement power have appeared in the literature, each claiming to represent the original legislative intent.

The first model envisions the most limited role for government in the collective bargaining process: the NLRB's reviewing power

59 See notes $47-53$ supra \& accompanying text.

6029 U.S.C. $\$ 158(\mathrm{a})(5)(1976)$.

61 But see Cox \& Dunlop, Regulation of Collective Bargaining by the National Labor Relations Board, 63 HAqv. L. REv. 389 (1950). Cox \& Dunlop argued that the "normal meaning" of the terms of section 8(5) would require nothing more of an employer than "to accord recognition to the representative designated by the employees and to accept in good faith the practices and procedures of collective bargaining." Id. 395. Their faith in the clarity of the language is not widely shared. 
would "not go beyond the office door" ${ }^{62}$ of the bargaining room. The employer would be required only to recognize and meet with representatives of his employees. The conduct and results of these negotiations would not be a matter for governmental inquiry.

The second model would allow the NLRB to review an employer's conduct during negotiations, in order to ensure that he bargained in good faith. ${ }^{83}$ The government would be allowed to peer into the bargaining room to determine whether the employer's actions indicated a subjective intent to make every reasonable effort to come to agreement with the representatives of his employees. The NLRB would not, however, be empowered to review the substantive terms of the employer's offer.

The third model is one of substantive review. Under this model, the NLRB would be empowered to compare the substantive terms of the employer's offer against an objective standard of reasonableness. An employer's failure to satisfy this criterion would constitute an unfair labor practice.

The fourth model is one of "unilateral compulsory arbitration." 64 Under such a model, the NLRB could specify terms, or a range of terms, it considered appropriate, perhaps as a remedy for a prior unfair labor practice. The employer would be forced to agree to such terms.

\section{B. Legislative History ${ }^{65}$}

Contrary to Klare's assertion, Congress defined a narrow role for the government in the administration of the collective bargain-

0279 CoNG. REc. 7659 (1935) (remarks of Senator Walsh).

63 The duty to bargain in good faith was first announced in Houde Eng'r Co., I N.L.R.B. (old) 35 (1934). The duty was incorporated into the statute by $\$ 8(d)$ of the Taft-Hartley Act, 61 Stat. 142 (1947), 29 U.S.C. $\$ 158(d)$ (1976):

[T]o bargain collectively is the performance of the mutual obligation of the employer and the representative of the employees to meet at reasonable times and confer in good faith with respect to wages, hours, and other terms and conditions of employment ...., but such obligation does not compel either party to agree to a proposal or require the making of a concession ....

This 1847 amendment seems to have codified the second bargaining model. The issue addressed by Klare and this Comment is which model conforms to the intention of the Congress that passed the Wagner Act. For the current understanding of the scope of the duty to bargain, see R. Gorman, BAsTC TEXT ON LABOR LAW 399-495 (1976); Cox, The Duty to Bargain in Good Faith, 71 Harv. L. REv. 1401 (1958).

64 This term seems to have originated with William $H$. Spencer, former Dean of the University of Chicago Business School. See W. Spencer, The National Labor Relations Act 23 (U. Chi. Sch. Bus., Studies in Bus. Admin., vol. 6, no. 1, 1935). See also Klare, supra note 3 , at 288.

65 For the definitive collection of congressional documents relating to the passage of the Wagner Act, see NLRB, Legistative History of the NationaL 
ing provision of the NLRA. Inconsistencies in the legislative history have engendered extensive debate concerning whether Congress understood the broad terminology as enacting model I or model II procedural review. ${ }^{86}$ Even the broadest reading of the legislative history, however, would empower the Board to review only the conduct, not the substance, of negotiations. Supporters and opponents of the Act agreed that the substance of collective agreements was to be left to the private ordering of the parties themselves; government would neither compel an employer and union to agree nor scrutinize the terms of the agreement. Private ordering, not government control, was the theme of this legislative provision.

As originally reported to the Senate Committee on Education and Labor, S. 1958-which became the Wagner Act-contained no reference to the refusal to bargain as an unfair labor practice. ${ }^{6 \tau}$ S. 2926, a similar bill introduced in the previous session of Congress, did contain such a provision: "It shall be an unfair labor practice for an employer . . . [t]o refuse to recognize and/or deal with representatives of his employees, or to fail to exert every reasonable effort to make and maintain agreements with such representa-

Labor Rerations ACT, 1935 (1949) (two volumes). For a discussion of the political circumstances surrounding the passage of the Act, see generally I. BERNStein, The New Deal Collective Barganning Policy (1950); R. Cortner, supto note 38; J. Gross, The Making of the National Labor Relations Board (1974).

${ }^{68}$ Cox \& Dunlop, supra note 61, argued that the plain meaning of the act, together with its legislative history, shows conclusively that the Congress that passed the Wagner Act intended the first model. Id. 394-95. "The Wagner Act was concerned with organization for bargaining-not with the scope of the ensuing negotiations nor with the procedures through which they are carried on." Id. 394 (emphasis in original). The authors thus considered improper the Board's adoption of a model II review standard, although they acknowledged that "[a]s a practical matter. . . , it is probably too late in the day to challenge successfully the NLRB's present practice of defining the scope of collective bargaining." Id. 397. See also Cox, supra note 63.

Miller, The Enigma of Section 8(5) of the Wagner Act, 18 IND. \& LAB. ReL. Rev. 168 (1965), drew a different conclusion from the legislative history. He argued that the framers of the Act intended that the Board "regulate the collective bargaining process." Id. 167; see id. 179-84. By "regulation," however, Miller meant a model II approach: the NLRB may "cross the threshold into the negotiating room, sit down with the parties at the table, and scrutinize the actions of the bargainers." Id. 176. Miller made no mention of any power vested in the NLRB to review the substantive terms of the employer's offer.

Smith, supra note 56, argued that the congressional intent as to the nature of the duty to bargain "cannot be clearly determined." Id. 1107. Although Smith personally favored granting the Board model III substantive review powers, id. II08, a careful reading of the evidence he presented supports the conclusion that such a role would have gone beyond the original legislative understanding. See notes 81-103 infra \& accompanying text.

67 See National Labor Relations Board: Hearings on S. 1958 Before the Senate Comm. on Education \& Labor, 74th Cong., 1st Sess. 17 (1935) [hereinafter cited as 1935 Hearings]. 
tives concerning wages, hours, and other conditions of employment." 88 Senator Wagner, who sponsored both bills, had the duty-to-bargain provision omitted from the 1935 bill because of the difficulties of casting the good faith bargaining requirement into satisfactory statutory language. ${ }^{60}$ Moreover, he "was particularly concerned that an explicit good faith bargaining requirement . . . would intensify and strengthen attacks on the bill by making it more vulnerable to charges that the law would require an employer to reach an agreement with a union and that the agreement be written-that is, a kind of compulsory arbitration." 70

Senator Wagner thought that the duty to bargain was "clearly implicit" in the bill, ${ }^{71}$ and would be established by the new NLRB on a common law basis. ${ }^{72}$ Francis Biddle, chairman of the old NLRB, insisted that the bill include an explicit duty to bargain, and introduced the language of what would become section $8(5) .^{73}$ His position was publicly supported by Lloyd Garrison, the first chairman of the old NLRB. Even admitting that the duty to bargain could be fairly implied from the bill as a whole, Garrison reasoned, "why leave it to possible interpretation by the Board when it is really to my mind the crux of the whole thing." 74 Garrison privately supported adding a provision clarifying "that the duty to bargain collectively would be satisfied by a requirement that the employer should meet with the union whenever requested at reasonable times," is but did not put the suggestion forward for fear of adding a complicating factor to the already difficult task of getting the bill through Congress. ${ }^{76}$

Section 8(5) was added to the bill, but its scope was not made explicit for another twelve years. ${ }^{77}$ The legislative history "contains repeated indications that the Act was not intended to require the parties to agree to anything, but just to meet and bargain." 78 Klare

68 To Create a National Labor Board: Hearings on S. 2926 Before the Senate Comm. on Education \& Labor, 73d Cong., 2d Sess. 353 (1934) [hereinafter cited as 1934 Hearings].

69 See 1935 Hearings, supra note 67, at 43 (statement of Senator Wagner); I. BERNSTEn, supra note 65 , at 95 .

$70 \mathrm{~J}$. Gross, supra note 65 , at 137.

711935 Hearings, supra note 67 , at 43.

72 I. BERNSTETn, supra note 65 , at 95 .

731935 Hearings, supra note 67, at 79.

74 Id. 137.

$75 \mathrm{~J}$. Gross, supra note 65, at 140 (citation omitted).

76 Id.

77 See note 63 stpra.

78 Klare, supra note 3 , at 307. 
discounts the weight of these remarks, yet they seem to show that the sponsors of the bill were aware that the duty to bargain was susceptible to divergent interpretations, and thus had sought to reassure their colleagues that no radical result was intended.

The congressional debates, hearings, and reports contain additional support for this interpretation of the Wagner Act. Responding to questions from a manufacturer during hearings concerning the purpose of the bill, then before the Senate Committee on Education and Labor, chairperson Walsh stated:

This bill would not compel you to accept any terms and conditions they may seek to impose on you, but you could not slam the door in their face, and you could not meet them in a hostile attitude, and in an attitude of unfriendliness, and in a predetermined disposition not to yield in any way and not to listen to them.

It does not tell you to enter into any agreement, but you are free to do as you wish about that. ${ }^{79}$

The Senate report similarly describes the model of collective bargaining contained in the bill as fundamentally one of private ordering:

The committee wishes to dispel any possible false impression that this bill is designed to compel the making of agreements or to permit governmental supervision of their terms. It must be stressed that the duty to bargain collectively does not carry with it the duty to reach an agreement, because the essence of collective bargaining is that either party shall be free to decide whether proposals made to it are satisfactory. ${ }^{80}$

The debates in the House and the Senate reveal a similar understanding of the collective bargaining provisions of the Act. Senator Walsh stated that:

[T] he bill requires no employer to sign any contract, to make any agreement, to reach any understanding with any employee or group of employees. . . .

791935 Hearings, supra note 67 , at 516.

80 Senate Comm. ON Education and Labor, National Labor Relations Board, S. Rep. No. 573, 74th Cong., Ist Sess. 12 (1935). The Senate Report was prepared by Senator Wagner at the request of Senator Walsh, chairman of the Senate Committee on Education and Labor. Its preparation was regarded as "a 
Nothing in this bill allows the Federal Government or any agency to fix wages, to regulate rates of pay, to limit hours of work, or to effect or govern any working condition in any establishment or place of employment. ${ }^{81}$

The debate on the House floor also made it clear that, although employers would be required to meet and confer with representatives of their employees, the labor bill was not meant to force the parties to agree at all, much less on any specific terms set by the government. For example, Representative Connery, the sponsor of the bill in the House, described an employer's duty in bargaining as follows:

The gentleman may say: "I will not give you the ten cents an hour increase you ask." There is nothing they can do then. Nobody asks that you be made to give them the ten cents an hour. This bill just compels you to deal with the men collectively. You must sit across the table and talk things over with them. ${ }^{82}$

Thus, the legislative history indicates that the bill was not intended to compel agreement or to allow the government to impose any specific substantive terms.

key opportunity ... to state congressional intent for the guidance of the board and the courts," I. Berwstens, supra note 65 , at 112 , and is thus deserving of great weight in determining legislative intent. statement:

s1 79 CoNg. REc. 7659 (1935). See also Senator Walsh's widely publicized

The bill indicates the method and manner in which employees may organize ... and leads them to the office door of their employer with the legal authority to negotiate for their fellow employees. The bill does not go beyond the office door. It leaves the discussion between the employer and the employee, and the agreements which they may or may not make, voluntary and with that sacredness and solemnity to a voluntary agreement with which both parties to an agreement should be enshrouded.

Id. The tenor of these remarks clearly indicates that Senator Walsh envisioned a model I review scheme.

Miller argues that Senator Walsh's remarks should not be taken as conclusive proof that the Congress understood that the bill it was considering would leave the employer's negotiating conduct immune from NLRB scrutiny. Miller, supra note 66, at 183-84. He hazards that the Senator's remarks may have been an overzealous attempt to explain "that bargaining was required only up to the point of impasse." Id. 183. Alternatively, he suggests that Walsh may have been purposefully understating the requirements of the bill, either to overcome congressional resistance, or to substitute his notion of the proper role of government in the collective bargaining process for the Senate committee's. Id. 184. But, even accepting Miller's analysis arguendo, it shows only that model II, not model III, conforms to the congressional expectation. See note 66 supra.

8279 CONG. REc. 9685 (1935). 


\section{The Smith Article}

Klare relies on legal scholar Russell Smith's 1941 article, The Evolution of the "Duty to Bargain" Concept in American Law, ${ }^{83}$ for the proposition that Congress left open the possibility of government scrutiny of the substantive outcomes of collective bargaining. ${ }^{84}$ Smith suggested in his concluding remarks that Congress had not thought out the collective bargaining concept sufficiently to determine whether it desired "something in the nature of a system of compulsory arbitration." 85 But Klare's exclusive focus on these concluding remarks, which lack the specificity and detail of Smith's earlier discussion of the experience of prior labor boards and of the Wagner Act's legislative history, leads him to an inaccurate conclusion regarding the Act's radical possibilities.

Smith predicted that the good faith standard, described as including "the duty of the employer to make counterproposals and to make every reasonable effort to come to an agreement," 86 would prove incompatible with purely procedural review. He based this assessment primarily on the experiences of prior labor boards that interpreted statutes implicitly or explicitly containing a duty to bargain. ${ }^{87}$ These boards, especially the first National Labor Relations Board, had developed legal standards for the employer's duty to bargain in good faith. Bad faith, although said to be a function of the employer's subjective state of mind, was determined on the basis of his objective actions, including the conduct of negotiations. While the previous boards had stopped short of interpreting this duty as giving them the authority "to judge objectively . . . the

83 Smith, supra note 56.

84 Klare, supra note 3 , at 288 \& n.73.

85 Smith, supra note 56 , at 1107 .

86 Id. 1088. This duty derived from Houde Eng'r Co., 1 N.L.R.B. (old) 35 (1934), which was quoted by Senator Wagner in his explanation of $\$ 8(5)$. See 79 Conc. REc. 7571 (1935) (remarks of Senator Wagner); Smith, supra note 56, at $1084-86$.

87 Smith briefly surveyed the pronouncements of the War Labor Conference Board, Smith, supra note 56, at 1067-70, and the Railroad Labor Board, id. 1070-75. He then discussed the experiences of the predecessors to the National Labor Relations Board: the National Labor Board and the National Labor Relations Board (old). Id. 1076-82. The National Labor Board was created in August 1933 to interpret and administer the provisions of section 7(a) of the President's Reemployment Agreement, a blanket code seeking to bring industries under the National Recovery Act (NRA). Id. 1076-77.

The National Labor Board was superseded by the first National Labor Relations Board which was established July 9, 1934 pursuant to H.R.J. Res. 44, 73d Cong., 2d Sess., 48 Stat. 1183 (1934). This Board, like the National Labor Board, was created to administer the labor provisions of section $7(a)$ of the NRA. Smith, supra note 56, at 1079 . 
reasonableness of the employer's contentions and proposals," such review logically would have been the next step. ${ }^{88}$

The passage of the Wagner Act, according to Smith, failed to clarify the nature of the employer's duty. Smith acknowledged the force of the legislative pronouncements referred to in the previous section ${ }^{89}$ of this Comment, but pointed out that, even while protesting that the scope of the duty would be limited, supporters of the Act seemed to approve of the prior board's more expansive approach to defining the duty. ${ }^{90}$ Smith concluded that, in light of these contradictory indications, legislative intent "cannot be clearly determined," 91 and that the task of determining the content of the duty "was left to the new Labor Board and to the courts." 22

Smith contended that from 1935 to 1941 the NLRB in fact had interpreted its mandate to include model II scrutiny of employer's negotiating conduct, and already had begun to blur the line between reviewing conduct and reviewing the reasonableness of offers. ${ }^{93}$ Smith encouraged the NLRB and the courts to continue this trend, ${ }^{94}$ and expressed a belief that this standard of review could be justified by the Act's overall goal of preventing strikes.95 Smith also suggested that the employer's duty to make counterproposals and to make every reasonable effort to come to agreement could be said to justify objective assessment of the reasonableness of the employer's arguments and proposals. ${ }^{96}$

Smith argued persuasively for the adoption of substantive review powers by the Board. Klare's use of this source, however, to support the proposition that Congress in passing the Wagner Act intended and was perceived as intending to confer such power upon the NLRB is inappropriate. Smith himself acknowledged that "the

$88 \mathrm{Id} .1080$ (emphasis in original).

89 Id. 1065, 1084-89; see text accompanying notes 65-82 supra.

${ }^{90}$ Smith, supra note 56, at 1086. Smith pointed to Senator Wagner's approving reference to Houde Eng'r Co., 1 N.L.R.B. (old) 35 (1934), on the Senate floor. Smith, supra note 56, at 1086; see 79 Cong. Rec. 7571 (1935). Houde had required employers to match the union's "proposals, if unacceptable, with counterproposals, and to make every reasonable effort to reach an agreement." Houde Eng'r Co., 1 N.L.R.B. (old) at 35.

91 Smith, supra note 56, at 1107.

82 Id. 1089.

93 Id. 1097.

$94 \mathrm{Id} .1108$.

95 Id. 1089 n.63 ("If an employer recognizes, meets and confers with the union, but remains adamant, unyielding and unreasonable in his attitude and proposals, and the union should strike in consequence, could not the union with some reason insist that it had struck because of the employer's failure to engage in genuine bargaining?").

${ }^{96}$ Id. 1088; see note 90 supra and note 86 supra \& accompanying text. 
framers of the act sought to distinguish between refusals to bargain and refusals to yield on specific wage, hour and other issues . . .," 97 although he himself doubted whether this distinction could or should be put into practice. Smith concluded that " $[t]$ he most that can be said is that such a technique seems to have been used, perhaps inadvertently, in a few cases, and that progression to this phase as an accepted practice could logically be made in line with principles announced [in the cases] concerning the meaning of section 8(5)." 98 Klare's attempt to prove that the Act was deradicalized by the judiciary is thus seriously flawed. If the NLRB, with the approval of the Supreme Court, had explicitly declared its power to undertake substantive review, perhaps Congress would have acquiesced, and perhaps the radical effects Klare predicts would have come to pass. In light of the clear trend of the legislative history, however, such a course of events would have had to be seen as a radicalization of the Act by the NLRB and the Court.

Flaws in Smith's argument also make Klare's reliance on him inappropriate. Smith's suggestion that substantive review could be justified by the Wagner Act's general goal of decreasing the frequency of strikes does not support the idea that substantive review was consistent with the original conception of the Act. The goal of reducing strikes could have been implemented in many different ways. Congress chose to enact a duty to bargain, but to leave the determination of substantive outcomes to the relative economic strength of the parties. It thus misconstrues the legislative history to suggest, as Klare does, that the Court jettisoned a result possibly intended by Congress. Rather, the Court merely refrained from encouraging the NLRB to extend its powers beyond those delegated by Congress.

Similarly, the duty to make counterproposals, arguably contained within section $8(5),{ }^{99}$ is not equivalent to substantive scrutiny of the terms of wage offers, even if it "obviously means a duty to make an agreement, upon acceptance of such counterproposals." 100 Requiring an employer to accept terms that he has proposed is not forcing him to concede or compromise anything to which he has not already agreed, or to accept any term that the other party or the government has suggested. Thus, the counterproposal component of the good faith standard is consistent with the evidence in the

97 Smith, supra note 56, at 1086 n.63.

98 Id. 1107.

99 See note 90 supra and note 86 supra \& accompanying text.

$100 \mathrm{Smith}$ supra note 56 , at 1088. 
legislative history showing that Congress intended that the government play a limited role in the collective bargaining process. ${ }^{101}$

\section{Contemporaneous Views of the Duty to Bargain}

This section surveys the views of concerned interest groups on the scope of the collective bargaining provision enacted as section $8(5)$. The evidence suggests that the Act was understood by its supporters as enacting either the first or second procedural review model; indeed, such a model seems to have been the only one acceptable to the labor unions and legal scholars, although for different reasons. The business community and some radical groups did characterize the duty to bargain as a form of compulsory arbitration; however, these characterizations can best be understood as efforts to prevent the passage of the Act by portraying it in the least appealing light possible.

The evidence surveyed in this section lends support to two important conclusions: that the passage of the Act by an overwhelming vote was facilitated by a common understanding among its proponents that the NLRB would only undertake procedural review, and that no important contemporaneous groups favored what Klare perceives as a radical, but reasonable, interpretation of section $8(5)$. Even assuming the relative autonomy of legal consciousness, ${ }^{102}$ it is difficult to argue that the Court could have ordained a system of substantive review in this political context. At the very least, the Court cannot be accused of deradicalization for its failure to enact such a model.

\section{A. Scholars and Commentators View the Duty to Bargain}

Klare's assumption that commentators at the time of the Wagner Act's passage saw in it the fulfillment, with respect to labor contracts, of the prophecy 'that the days of 'freedom of contract' were numbered" 103 is not borne out by the historical evidence.

101 Smith himself stated that this compulsion is unlike that involved in a system of compulsory arbitration. Smith implied that there is no significant compulsion if one is free to refuse to agree except on one's own terms, although he did indicate that the imposition of a statutory duty to bargain adds "a certain additional element of compulsion." Id. 1107. In his concluding remarks, he wrote that: "The subject for investigation herein, however, has been whether such statutory obligation involves the further possibility that the bargainer, who would normally be free ... to refuse to agree except upon his own terms, is no longer free to do so." Id. (emphasis added).

102 See note 39 supra.

103 Klare, supra note 3, at 293. 
Although scholars and commentators of that time debated whether Section $8(5)$ proposed a system of compulsory arbitration, this view -which would conflict with the private-ordering model emphasized in the congressional records ${ }^{104}$-was not seen as the most desirable or plausible interpretation..$^{105}$

Scholars commenting on the collective bargaining provision of the new Act noted the limitations that Congress had imposed on government intervention. For example, one commentator wrote that:

Neither under Section $7 \mathrm{a}$ nor under the Wagner-Connery Act has it been the intention of the legislature to force employers to make or subscribe to agreements they find unacceptable. Had that result been intended and had Congress been willing to accept responsibility for compulsory arbitration, the boards might have been empowered to compel the making of agreements drawn up under its supervision. ${ }^{106}$

Because Congress did not explicitly give the National Labor Relations Board the power to compel agreements, this commentator argued, compulsory arbitration should not be read into section $8(5)$ of the Wagner Act.

The possibility that the Wagner Act could be interpreted as establishing a system of compulsory arbitration stimulated concern about the constitutionality of such legislation. Although most constitutional criticisms focused upon the Act's commerce clause basis, scholars also questioned whether the collective bargaining provision violated the due process clause. ${ }^{107}$ These objections, how-

104 See notes 65-81 supra \& accompanying text.

105 See, e.g., Latham, Legislative Purpose and Administrative Policy under the National Labor Relations Act, 4 Gro. WASH. L. REv. 433, 467 (1936) (arguing that the Act does not force employers to agree and thus does not impose compulsory arbitration); Mason, The Limits as to Effective Federal Control of the EmployerEmployee Relationship, 84 U. PA. L. REv. 277, 302-03 (1936) (asserting that "[t]he attempt of government (if made) to force agreements . . . [would] smack of compulsory arbitration"); Note, Constitutionality of the National Labor Relations Act, 4 U. CEn. L. REv. 109, 110-13 (1936) [hereinafter cited as Chicago Note]; Note, The National Labor Relations Act-Constitutional and Statutory Problems, 30 IrL. L. REv. 884, 918 (1936) [hereinafter cited as Illinois Note]; Comment, The National Labor Relations Act, 3 U. PIrT. L. REv. 33, 45-46 (1936) [hereinafter cited as Pittsburgh Comment]; 35 Corum. L. REv. 1098, 1123 (1935) (asserting that the bargaining provision does not require the employer "to temper his final decision as to wages or hours"). See also 22 ConNELl L.Q. 151, 152 n.24 (1936) (noting, but not evaluating, the possible argument that the Act imposes compulsory arbitration).

108 Latham, supra note 105, at 467.

107 The Act was declared constitutional in NLRB v. Jones \& Laughlin Steel Corp., 301 U.S. I (1937). For a description of the constitutional issues in con- 
ever, were not considered very serious. ${ }^{10 s}$ For example, one law review Comment, examining the Act's possible interference with freedom of contract, stated that "it has been argued that the Wagner Act . . . establishes 'compulsory unilateral arbitration,' . . . [but] [n]o provisions of the Act compel the employer to accept any terms which the representatives of the employees offer." 109

Other scholars viewed the legislative provisions as amenable to an interpretation closer to a system of compulsory arbitration, but they argued that only a collective bargaining statute premised on a private-ordering model could withstand the constitutional test. For example, one scholar commented that " $[t]$ he attempt of government (if made) to force agreements between employers and organized labor . . . smack[s] of compulsory arbitration, and the compulsory method of dealing with the industrial problem has found little favor with the Supreme Court." ${ }^{110}$ Another commentator similarly described this problematic construction of the collective bargaining provision. Believing that, "if this section is to be interpreted so as to force the employer to enter into collective agreements, it will operate as a species of 'unilateral compulsory arbitration,' "111 this author urged that the duty to bargain in good faith therefore should not be interpreted as compelling the employer to accept an agreement. In this way, the potential constitutional problems could be avoided: "Hence it would seem that a construction which would place any duty upon the employer much greater than that of preceding his decision by a conference would raise such grave constitu-

troversy before the Jones \& Laughlin decision, see I. BERNSTEIN, supra note 65 , at 104-07, 113-16, 139-41; R. ContNer, supra note 38, at 50-73; Chicago Note, supra note 105; Illinois Note, supra note 105; 22 CoRNent L.Q. 151 (1936). See generally L. TRmE, supra note 30 , at $434-55$.

108 See, e.g., 35 Corum. L. REv. 1098, 1123 (1935). But see NLRB v. Mackay Radio \& Tel. Co., 87 F.2d 611 (holding the Act unconstitutional on due process grounds), aff'd on rehearing, 92 F.2d 761 (8th Cir. 1937), rev'd, 304 U.S. 333 (1938).

Klare relies on this circuit court opinion and on Smith's article, supra note 56, to support his claim that commentators and courts viewed the passage of the Wagner Act as marking the end of freedom of contract as the governing ideology with respect to labor relations. Klare, supra note 3, at 293 \& n.87. In so doing, Klare ignores the scholarly publications presented in this section that contradict his point.

109 Pittsburgh Comment, supra note 105, at 45-46. See, e.g., NLRB v. Associated Press, 85 F.2d 56, 61 (2d Cir. 1936) ("The employer retains full control to bargain with his employees over the wage he shall pay and the working conditions he shall furmish. He remains the master of the operation of his business."). But see Pratt v. Stout, 85 F.2d 172, 178-80 (8th Cir. 1936); Bendix Prods. Corp. v. Beman, 14 F. Supp. 58, 69-70 (N.D. Ill. 1936).

110 Mason, supra note 105, at 303.

111 Illinois Note, supra note 105, at 918. See also Chicago Note, supra note 105, at $110-11$. 
tional doubts as to its validity that the section must be construed so as to avoid such doubts." 112

Scholars, sensitive to potential constitutional challenges to the Wagner Act, therefore interpreted the collective bargaining scheme as imposing on employers only procedural requirements, such as the duty to meet and discuss terms and conditions of employment. To be operative, these commentators argued, collective bargaining had to remain within the private-ordering framework. The scholars closest in time to the passage of the Wagner Act thus did not perceive it as containing radical possibilities. ${ }^{113}$

\section{B. Unions View the Duty to Bargain}

The American union movement embraced the terms and spirit of the National Labor Relations Act. ${ }^{114}$ Although specific structures and procedures were disputed, the American Federation of Labor (AFL) and its affiliates worked for the passage of this legislation, including an employer duty-to-bargain provision. ${ }^{115}$ Consistent with the historical experiences and ideological traditions of organized labor, however, the union movement did not seek government scrutiny of the substance of the wage bargain.

Labor leaders testifying before Congress did not describe clearly the collective bargaining model they envisioned, although there are strong indications that a procedural model was preferred. William Green, the President of the AFL, epitomized this ambiguity in his 1934 and 1935 appearances before a Senate committee during the debates on the Wagner Act and a predecessor bill. In his 1934 presentation, Green described several "facts" that had to be faced before considering the bill, including that "if collective bargaining

112 Illinois Note, supra note 105, at 918.

113 It could be argued that these commentators' views support Klare's hypothesis that "the law itself, as a legitimizing ideology and a system of institutions, played a role in the deradicalizing process," Klare, supra note 3 , at 291 n. 79 , if one surmised that these legal scholars viewed certain potentially "radical" features of the Act as unconstitutional only because their analyses "were mediated through, and in part determined by, the new legal consciousness," id. 292. This argument, however, would contradict Klare's assertion that the Court "articulate[d] a new legal consciousness respecting labor matters." Id. These law review articles instead lend support to the conclusion that the terms of the Wagner Act were molded to conform to the acceptable realm of legal consciousness from the inception, and that the radical potential Klare sees in the legislation was never taken very seriously by the legal community.

114 I. Bernstein, supra note 65 , at 89 ; I. Bernstein, Turbulent Years 324 (1969); G. Higgins, Voluntarism In Organtzed Labor In The United States, $1930-40$, at 83 (1944).

115 See, e.g., 1935 Hearings, supra note 67, at 101-23, 188-99 (statements of William Green and John L. Lewis); I. BERNSTEIN, supra note 65 , at 89. 
is to be carried out, it must be forced upon some employers." 110 This type of statement could be interpreted to mean that uncooperative employers would be compelled to engage in the bargaining process. Yet one Senator was prompted to inquire whether Green favored compulsory arbitration:

SENATOR DAvis: [D]id I get a slight notion that you were more or less favoring compulsory arbitration?

MR. GREen: No, sir; and the bill does not provide for compulsory arbitration.

Senator Davis: I know the bill does not provide for it . . . ; but . . . it was creeping into my mind, at least, that you were leaning toward compulsory arbitration.

Mr. Green: Well, I want to relieve that impression because we do not favor, nor do we ask for compulsory arbitration as applicable to either employers or employees. ${ }^{117}$

Thus, the President of the AFL said that he neither supported compulsory arbitration nor saw such a model in an early version of this legislation.

A year later, Green's testimony before the Senate committee on the revised bill cast some doubt upon his adherence to a purely procedural model of the duty to bargain. Green stated that "it must be recognized by both parties that the goal sought is not achieved until a definite agreement has been reached." 118 Although Green was not pressed further on this point, the context of his statement suggests that he was primarily concerned with insuring that employers undertake their bargaining obligation with a proper attitude. He emphasized that "cooperation," "mutual confidence," and "mutual respect" were the goals to be achieved by the legislation.110 Although Green did not confront the issue how this attitude was to come about and be enforced, he never suggested that government should assume powers of substantive review to ensure a proper bargaining relationship. ${ }^{120}$

1161934 Hearings, supra note 68, at 70 (statement of William Green).

117 Id. 73.

1181935 Hearings, supra note 67, at 103 (statement of William Green).

110 See, e.g., id.

120 Green did foresee the government resolving disputes when the parties did not agree, and he even once termed this arbitration. Id. 114. Yet, because of his somewhat idealized vision of what collective bargaining would be like once unions gained formal recognition, he did not urge that the government insure the faimess of collective agreements by substantive scrutiny. Green believed that, once organizational and bargaining rights were recognized, "mutual confidence, mutual respect, 
This preference for procedural review, despite its inherent internal tensions, stemmed from the ideological traditions of the American labor movement. Voluntarism had been the guiding philosophy of the AFL since the days of Samuel Gompers in the late nineteenth century. ${ }^{121}$ Voluntarism implies acceptance of the capitalist economic system, and encouragement of worker organizations to join the struggle of competing economic groups to gain their share of societal goods. Because workers themselves were thought to best understand their needs and interests, self-activity was relied upon to reach their goals. Government aid was disfavored relative to self-help, because the government was not trusted to be neutral. ${ }^{122}$

Labor legislation like the National Labor Relations Act was problematic for labor leaders steeped in this voluntarist tradition. Nevertheless, as employer tactics caused the labor movement great difficulty in its organizational and bargaining efforts, organized labor began to welcome labor legislation. The AFL embraced the NIRA, seeing it as legislation in line with its voluntarist ideology, because the Act's codes of industrial behavior would be designed collectively by industry and labor representatives. ${ }^{123}$ In the words of one historian, "the AFL could understand the NIRA to be a species of governmental encouragement for employer-employee regulation of the industrial sphere by mutual conference, bargaining, and negotiation." 124 Because labor was to have a critical role in shaping the terms and conditions of industrial life, the AFL could support this legislation.

Experience with code making under the NIRA led the AFL to reaffirm its commitment to voluntarism and to decry government intervention in labor relations. By 1934, labor leaders were urging workers not to rely on government aid to improve their conditions. Self-help through labor organization and collective bargaining was emphasized because labor leaders believed that the code-writing

and a genuine willingness to give and take until equitable settlement is arrived at"which in his view lay at the heart of the statutory scheme-would develop spontaneously. Id. 103.

121 See generally G. Higgrns, supra note 114; R. Honowitz, Poltticar IDEOLOGIES OF ORGANIZED LABOR (1978). at 27-42.

122 See G. Higgns, supra note 114, at 2-3; R. Honowriz, supra note 121,

123 R. Honowitz, supra note 121, at 102-04.

124 Id. 103 (citation omitted). But cf. G. Hicgins, supra note 114, at 80-81 (noting that labor's support of the NIRA could be viewed as an abandonment of voluntarism). 
process had become dominated by business interests. ${ }^{125}$ These experiences under the NIRA made labor skeptical of an increased role for government in regulating labor relations.

Although the unions believed that the ultimate victories for labor would come through their own efforts in organizational drives and at the bargaining table, the labor movement did recognize that it was the strength of business that had brought about the failure of the NIRA code-making machinery. ${ }^{120}$ The AFL, therefore, did enlist the support of the federal government to compel employers to recognize and bargain with employee representatives. ${ }^{127}$ Thus, in 1934 and 1935, before congressional committees and their own constituencies, labor leaders supported the passage of the Wagner bill, urging the creation of a strong government board that could enforce workers' rights to organize, to select a representative of their own choosing, and to bargain with their employer.

Tensions between distrust of government aid and the need for help in combatting the overwhelming strength of the employers lay behind labor's endorsement of the Wagner Act. Although they never precisely defined what model of collective bargaining they desired the unions' past traditions and experiences create a strong inference that a procedural review model was preferred. Government help was needed to force the employer to recognize and bargain with labor representatives, but beyond that labor seems to have believed that it could best win equitable agreements from employers without government interference in the substance of the wage bargain.

\section{Employers View the Duty to Bargain}

Most employers, as Klare points out, "bitterly opposed passage .of the [Wagner] Act." ${ }^{128}$ The American Liberty League ${ }^{129}$ and the National Association of Manufacturers ${ }^{130}$ were the most vociferous employer organizations devoting their considerable resources to defeating the bill. Once the Act became law, these employer groups .110-12.

125 See G. Higcins, supra note 114 , at $80 ; \mathrm{R}$. Honowrrz, supra note 121 , at

126 R. Honowriz, supra note 121, at 112.

127 Id. 112-13.

128 Klare, supra note 3, at 266; see I. BERNster, supra note 65, at 106-10.

120 See I. Bernstemn, supta note 114, at 450, 515, 646; R. CortNER, supra - note 38 , at $51-53$.

130 See I. Bernstein, supta note 65 , at 110; R. ContNer, supra note 38 , at 54; J. Gross, supra note 65 , at 138-42. 
worked to resist its implementation..$^{131}$ When the Supreme Court: declared the Wagner Act constitutional, employers redirected their attention to Congress and attempted to procure amendments favorable to their interests. ${ }^{132}$

Employers opposed the bill because they perceived it as unwarranted government intrusion into their exclusive domain. The extent to which section $8(5)$ added to their opposition is unclear. Certainly, they would have preferred a bill that contained no duty to bargain. Because section $8(5)$ was not in the original bill, however, but was added by the Senate committee, employer opposition did not focus on this provision. Instead, employers targeted other aspects of the bill, in particular its constitutional foundation, the unilateral character of the obligations it imposed, and its emphasis on majority rule. ${ }^{133}$

Once the bill became law, with its duty to bargain provision intact, employers and their allies were quick to denounce it as imposing compulsory arbitration in the guise of a collective bargaining procedure. $^{134}$ Klare seems to use these statements as support for the proposition that the Act could have realistically been interpreted by the Supreme Court as mandating compulsory arbitration. ${ }^{135}$ The alarmist rhetoric of business groups, however, should not be taken as proof that the Act actually contained the potential for such a radical restructuring of relationships within the workplace, any more than the predictions made by radical groups that the Act would destroy labor unions ${ }^{136}$ should be taken as proof that Congress intended such a result.

\section{Radicals View the Duty to Bargain}

This section examines the attitudes of selected radical organizations toward the Wagner Act and its collective bargaining provision at the time the Act was passed. ${ }^{137}$ These organizations were

131 See I. Bernstein, supta note 114 , at 349, 450,639, 646-50; R. Cortner, supra note 38 , at $62-69$; Klare, supra note 3 , at 286-89.

132 See, e.g., I. Bernstenn, supra note 114, at 663 ("The Chief Justice had hardly concluded the reading of the Jones \& Laughlin decision when the Chamber of Commerce called for 'equalizing' amendments to forbid unfair practices to employees, to regulate unions, and to restrict Board jurisdiction.").

133 See, e.g., 1935 Hearings, supra note 67, at 240-266 (statement of James Emery, General Counsel of the National Association of Manufacturers).

${ }^{134}$ See, e.g., W. Spencer, supra note 64 , at 24.

135 Klare, supra note 3 , at 266-67, 288.

136 See notes 137-92 infra \& accompanying text.

137 For a description of prominent radical groups and ideologies during the thirties, see S. LENS, RAdicalism In AMrenica 302-06 (1966). For information 
.chosen for examination because they represent different segments of the left wing in the mid-1930s, and because they published their views toward the Act. The groups uniformly opposed the Wagner Act, largely because they feared that its passage would involve the government too deeply in the collective bargaining process. Indeed, their distrust of government led them to predict dire results if the Act became law, in terms that, ironically, echoed the opposition of business. 138

The antagonistic attitude of the organized left toward the Wagner Act undermines Klare's interpretation of the legislation. Even if the Supreme Court had turned to the left for guidance, it would have found no support for interpreting the Act as empowering the government to regulate the terms of the wage bargain. Thus, the one view that united business, labor, and radicals was that the government should narrowly define its power to police the results of the collective bargaining process. Even if the legislative history had been more ambiguous, it seems farfetched to posit that the Supreme Court could have mandated substantive review in the face of opposition from even these segments of society.

\section{The Lovestoneites}

The Lovestoneites, also known as the right opposition group, were expelled from the Communist Party in 1929 for espousing the view that the United States was not ready for revolution. ${ }^{139}$ They published the newspaper Workers Age from 1932 until about 1940, when the group disappeared. ${ }^{140}$ Although the Lovestoneites never had a large membership ${ }^{141}$ and were never politically powerful, ${ }^{142}$ they do illustrate that even a relatively moderate radical group that had supported some New Deal social legislation was deeply distrust-

. about radicals' attitudes toward the Wagner Act, see S. Aronowrtz, Farse Promises -239 (1973); P. Conkin, FDR and the Onigins of the Welfare State 56-57 (1967); C. Daniel, The ACLU and the Wagner ACt (1980).

138 See text accompanying notes 128-36 supra.

${ }^{139}$ A group led by Jay Lovestone was a major faction within the American - Communist Party during the 1920s until their expulsion in 1929. See I. Howe \& L. Coser, The Amerucan Communist Party 144, 152-74 (1957); S. Lens, supra note 137, at 302; Riepe, Introduction, I Workers Age (1932) (1968 reprint series).

140 See S. LENs, supra note 137, at 306; Riepe, supra note 139.

141 The group's membership was probably no greater than one thousand or ffifteen hundred, see S. LeNs, supra note 137 , at 306 , although it is uncertain how - widely their publication Workers Age was read.

142 N. Glazer, The Soctal Basts of American Comomunism 59 (1961) (indicating that only a handful of members followed the Lovestoneite leadership out vof the party and that no major foreign-language group or newspaper went with it). 
ful of a bill that gave the government an important role in the collective bargaining process.

The Lovestoneites opposed the New Deal labor legislation granting workers organizational, recognitional, and bargaining rights, ${ }^{143}$ and criticized the creation of government boards to administer the regulatory schemes. ${ }^{144}$ They argued that this legislation would undermine the strength of labor organizations, which they believed to possess great potential for restructuring society. For example, the Lovestoneites criticized the plan for creating a National Labor Board, ${ }^{145}$ on which labor, management, and public representatives were to sit, arguing that unions could not simultaneously collaborate with their antagonists and serve their rank and file members:

For a union to fulfill its elementary function of defending the economic interests of the workers against the employers, it must be completely and unconditionally free of any entangling alliances with the capitalists, their organizations and their government. The Roosevelt plan, providing for union participation in a whole maze of government boards, completely dominated by trust capital, strives to make the organizations of labor the vehicles for carrying out the plans of the capitalists. ${ }^{146}$

The Lovestoneites feared that giving government the power to intervene in labor disputes would undermine the activist role of unions in winning better wages and working conditions for their constituents. Writing about section 7(a) of the National Industrial Recovery Act, which provided "that employers shall comply with the maximum hours of labor, minimum rates of pay, and other conditions of employment, approved or prescribed by the President," 147 the Lovestoneites declared: "If workers cannot look to their unions to fight for them to settle hours and wages, if the

143 See Herberg, Labor and the National Recovery Act, Workers Age, Aug. 15, 1933, at 3, col. 1; Herberg, The Recovery Act and the Workers, Workers Age, July 1, 1933, at 3, col. I; Lovestone, At First Glance, Workers Age, Apr. 27, 1935, at 1 , col. 1 .

144 See Roosevelt Rules the Roost in Capital But Green is Balking, Workers Age, Feb. 23, 1935, at 1, col. 3. 1076-77.

145 See generally J. Gross, supra note 65, at 15-18; Smith, supra note 56, at

146 Herberg, The Recovery Act and the Workers, Workers Age, July 1, 1933, at 3 , col. I; 7, cols. 1-2.

147 National Industrial Recovery Act, ch. 90, $\$ 7(a), 48$ Stat. 198 (1933) (declared unconstitutional in Schechter Poultry Corp. v. United States, 295 U.S. 495 (1935)). 
President can by his own decree, arbitrarily determine everything, do and undo anything, then what are unions for?" 148 The Lovestoneites also opposed the Wagner Act, which they believed to pose "the permanent danger of a concentration of power in the hands of the executive over the lives of the working class and its organized movement." 140

The Lovestoneites opposed the New Deal labor legislation because they believed that the government was fundamentally an instrument of the capitalist class, ${ }^{150}$ and that the larger the role of the NLRB, the courts, or the President, the more the interests of the workers would be jeopardized. As an article in Workers Age stated:

The Wagner proposal leaves the labor organizations wide open to arbitrary rule, to reckless interference, to dictation by hostile government boards, as well as by a hostile President. We underscore the word 'hostile' because there hasn't been a President and there hasn't been a government board which in practice was not doing the bidding of big business against labor, particularly in fundamental issues. ${ }^{161}$

The Wagner Act "gave sweeping powers to the United States government . . . to step into all labor disputes and itself decide who is right. . . . Thus it increased the power of capitalist government to bring the trade unions under its control, and therefore under the direct rule of the bosses." 152

148 Herberg, Labor and the National Recovery Act, Workers Age, Aug. 15, 1933, at 3 , cols. $1 \& 5 ; 4$, col. 2 (emphasis omitted).

149 Brown, Wagner Act Bulwark of Company Unionism, Workers Age, Jan. 23, 1937, at 5, cols. 1, 3. See Lovestone, supra note 143; The Wagner Bill, Workers Age, June 1, 1935, at 1, col. 2.

150 Although the Lovestoneites did not support increased government supervision of collective bargaining, they did recognize the benefits of bringing wage issues to public prominence. In a 1933 article, an editor of Workers Age wrote that "[t]he public recognition of the sub-starvation wage standards of the depression era as the new and legally declared 'American standard of living' will be the great achievement of the National Industrial Recovery Act." Herberg, supra note 146, at 7, cols. 2-3. Despite the Lovestoneites' recognition of the benefits of increased public discussion of these issues, they still criticized legislation that increased govermment involvement in labor-management relations, characterizing such reform efforts as designed by the capitalists to oppress the workers. See, e.g., id. 7, col. 2. This contrasts sharply with Klare's views on this issue, see notes 47-53 supra \& accompanying text.

151 The Wagner Bill, Workers Age, June 1, 1935, at 1, col. 2.

152 Courts Rehearsing Wagner Act Ruling, Workers Age, Apr. 4, 1936, at 2, cols. 3, 4. See also For a Labor Party in the United States, Workers Age, Jan. 19, 1935, at 1, col. 1 (special supplement). 
Like business leaders ${ }^{153}$ and other opposition groups, the Lovestoneites characterized the Wagner Act as providing for compulsory arbitration. ${ }^{154}$ They criticized the Act for forcing agreements between corporations and workers, and for empowering the Board "to pass judgment upon the motives, objectives, and economic arguments of the trade unions." 155 Their opposition to what they perceived to be a greatly increased role for the government in labormanagement relations seems to have been based on their fears that. this would undermine the essential functions of unions and that. the government would necessarily favor the capitalists. At the timeof the passage of this New Deal legislation, then, this radical group did not embrace the ideals that Klare characterizes as the radical potential of the Act. ${ }^{158}$

\section{The ACLU and the Communist Party}

The American Civil Liberties Union (ACLU) and the Communist Party, representing the mainstream of the radical left, shared the Lovestoneites' opposition to the Wagner Act and the Act's dutyto-bargain provision.

The ACLU, ${ }^{157}$ whose board of directors was dominated by leftists during the thirties, ${ }^{158}$ opposed both the labor provision of the National Industrial Recovery Act ${ }^{159}$ and the enactment of the National Labor Relations Act. ${ }^{180}$ Although internal dissension later

153 See text accompanying notes 128-36 supra.

154 See, e.g., Brown, supra note 149.

In an article detailing the legal strategy used by the U.S. Steel Corporation to thwart a union organizing drive, the Lovestoneites described the potential impact of the Act, and especially its appeal and enforcement mechanisms, as follows: "the system of compulsory arbitration, that is beginning to unfold and that is part and parcel of a state capitalist system, endangers trade union organization." Brown, Organizing Steel Under Wagner Law, Workers Age, Jan. 2, 1937, at 4, col. 4; 6, col. 4. Curiously, this article also stated that the Act did not "grant collective bargaining." Id. This misrepresentation can perhaps be explained as a reflection of the group's fundamental distrust of the Act.

155 The Wagner Bill, Workers Age, June 1, 1935, at 1, col. 2; 4, cols. 1, 2.

156 See generally Klare, supra note 3, at 291-93, 308-09 n.151.

157 The positions attributed to the ACLU in this subsection are those taken by its leadership, especially Roger Baldwin, the organization's founder and director.

158 Although only one board member, Robert Dunn, was a member of the Communist Party during this period, the organization collaborated with Communist groups in formulating its policies and programs, and Roger Baldwin was sympathetic to much of the Communists' economic and political philosophy. C. DaNIE,, supra note 137 , at $45,78-84,129-30$.

159 Id. 48-52.

$160 \mathrm{R}$. Continer, supta note 38 , at 57; C. DANIEL, supra note 137, at 97-104. 
forced the organization to adopt a neutral position toward the Wagner Act, ${ }^{101}$ the ACLU's leadership never saw this New Deal legislation as a panacea for the nation's economic and social maladies. Like the Lovestoneites, ${ }^{162}$ the ACLU feared giving an increased role to the government in labor-management affairs, and did not view the Wagner Act as radical legislation at the time of its passage.

The ACLU further believed that government intervention under the Wagner Act would, in the long run, weaken unions' aggressiveness and independence. The ACLU took the position that the purportedly pro-labor government protection of unions' right to organize, bargain collectively, and strike would ultimately work to the disadvantage of employees by making them dependent on the government. ${ }^{183}$ Workers' organizations, not governmental legislation, it was thought, would best serve the interests of working people. In a letter to Senator Wagner during the 1935 Senate hearings on his bill, Roger Baldwin, founder and leader of the ACLU, reported that the ACLU's board of directors had decided to oppose the legislation. Baldwin wrote that "only unions militant enough and strong enough to withstand many pressures have been able to achieve anything like an unrestricted exercise of their rights." 164 Defending the ACLU's position against the Act in 1935, Baldwin wrote to Francis Biddle, ${ }^{165}$ an ardent supporter of the legislation:

I venture to say that the government's mediation and intervention in all the major industries have tended to weaken the unions by encouraging reliance not upon themselves but upon government agencies. It has been our observa-

161 For an explanation of this important change in position, see notes 183-89 infra \& accompanying text.

162 See text accompanying notes 139-56 supra.

163 Although liberals and other members of the noncommunist left agreed that the most important and long-lasting victories were those labor won for itself, these groups did support the Wagner legislation. C. DANIEL, supra note 137, at 100. For a discussion of liberal attitudes, see id. 16-20, 22-24, 94-96.

164 C. DANLE, supra note 137, at 102 (quoting Letter from Harry F. Ward, Arthur Garfield Hays \& Roger N. Baldwin to Robert F. Wagner (April 1, 1935)).

165 Francis Biddle was chairman of the National Labor Relations Board, created in 1934 pursuant to Public Resolution No. 44 to take over from the National Labor Board the task of enforcing the labor provisions of the NIRA. See H.R.J. Res. No. 375, 48 Stat. 1183 (1934) (superseded by the National Labor Relations Act, ch. 372, $\$ \$ 2(11), 4(\mathrm{~b}), 49$ Stat. 449 (1935)). Biddle appeared before the Senate Labor Committee to testify in favor of the bill. Biddle wrote Baldwin: "Even under 7(a), innocuous as it is, the unions have grown in power and cohesion, and they would grow even more under the Wagner Bill." C. DANDE, supra note 137, at 106 (quoting Letter from Francis Biddle to Roger N. Baldwin (April 17, 1935)). 
tion that unions have won advances only where they have been strong enough to get them anyhow. ${ }^{186}$

The ACLU's denunciation of increased government intervention in labor-management relations was based on its belief that the government would not protect labor's rights, but would work to further the interests of the capitalists. The ACLU's 1934 annual report reflects this position:

The role of the New Deal in relation to labor's rights could easily have been forecast by those who understand that its main purpose is the preservation of the existing economic system. . . . Despite the unparalleled power of the federal government, effective control over the exercise of civil liberties in the United States rests where it always has been,-with the masters of property. ${ }^{167}$

Similarly, in his 1935 letter to Senator Wagner, Baldwin wrote:

We urge your consideration of the view that the pressures on any governmental agency from employers are so constant and determined that it is far better to have no governmental intervention than to suffer the delusion that it will aid labor in its struggle for the rights to organize, bargain collectively and strike. ${ }^{168}$

The ACLU thus viewed the Wagner Act's premise of government involvement in the labor-management bargaining process as inherently conservative and contrary to the interests of the workers.

The Communist Party ${ }^{169}$ and other radical groups ${ }^{170}$ also believed that government intervention in labor matters would only serve the interests of employers. ${ }^{171}$ Like the Lovestoneites, the

166 C. DANIEL, supra note 137, at 106 (quoting Letter from Roger N. Baldwin to Francis Biddle (April 18, 1935) ).

167 Id. 84 (quoting ACLU, Liberty under the New Deal: The Record for $1933-34$, at 3-10 (1934)).

168 Id. 102 (quoting Letter from Harry F. Ward, Arthur Garfield Hays \& Roger N. Baldwin to Robert F. Wagner (April 1, 1935)).

169 I. Howe \& L. Coser, supra note 139, at 232-33.

170 See generally S. AronowrTz, supra note 137, at 239 (indicating that radicals viewed the early New Deal as an effort to achieve stability in order to further the interests of the giant corporations); S. LENs, supra note 137, at 315 (noting that the Communists denounced Roosevelt's policies as carrying out the capitalists' attack against the masses).

171 Other noncommunist leftists did not share this opposition to labor legislation. Based on a survey of liberal publications of the period, historian Cletus Daniel has concluded that "liberals and non-Communist leftists did give solid support to Wagner's National Labor Relations bill." C. DANIEx, supra note 137, at 100. These groups did criticize the labor provisions of the NIRA, but their attacks focused 
Communist Party believed that the federal government was controlled by propertied interests. During the 1935 Senate hearings on the Wagner bill, William Dunne, representing the Communist Party, submitted a statement declaring that: "Government is the organized power of the dominant class. In the United States this is the capitalist class." 172 But the Communist Party did not oppose all legislative efforts to help working people and unions; in fact, Dunne's statement at the Senate hearings concluded by presenting the Party's proposals for labor legislation. ${ }^{173}$ The Communist Party did oppose Senator Wagner's bill, however, because it was a product of the Roosevelt administration, which they viewed as "the focus point for American fascist reaction." 174

The Communist Party feared that the Roosevelt administration's labor policies would impose compulsory arbitration by the federal government. During the 1935 Senate hearings, for example, William Dunne stated on behalf of the Party that: "We are opposed to the bill because it is a compulsory arbitration measure in essence. It sets up new police powers in industrial disputes to enforce compulsory arbitration directly under the control of Government agencies. Under such a bill, collective bargaining is a cruel brand." 175

The ACLU also feared the possibility of compulsory arbitration because they believed that such government intervention would result in interference with, and perhaps even abolishment of, the unions' right to strike ${ }^{178}$ In 1933, the ACLU joined radical labor leaders in presenting a statement to President Roosevelt protesting the labor provisions of the NIRA. ${ }^{177}$ The group urged the President to unequivocally condemn "any compulsory method of arbitration under which the right of workers to strike is hampered or suspended." 178 Similarly, when the ACLU informed Senator

upon administrative and enforcement problems; they did not view the legislation as part of a capitalist conspiracy to oppress the workers. See id. 45, 58-59, 95.

1721935 Hearings, supra note 67 , at 581.

173 Id. 586-87.

174 Id. 586.

175 Id. See also C. Daniel, supra note 137, at 49-51, 101.

176 The ACLU leadership recognized the importance of the workers' right to strike, and worried that this right would be compromised or lost with the advent of greater government involvement in labor-management struggles. See C. DANIEI, supre note 137, at 49,59,68, 93, 101. See generally J. Brecher, Strmke 233-42 (1972) (discussing the significance of strike activity in creating a radical restructuring of society).

177 See C. DANIEI, supra note 137 , at 48-52.

178 C. DANmer, supra note 137, at 51 (quoting Letter from A.J. Muste and others to Franklin D. Roosevelt (Sept. 19, 1933)). 
Wagner of its opposition to his 1935 bill, Baldwin wrote: "We say this from a long experience with the various boards set up in Washington, all of which have tended to take from labor its basic right to strike by substituting mediation, conciliation, or, in some cases, arbitration." 178 The ACLU thus feared that the Wagner Act would give the government the power to determine wages and other conditions of employment.

World events and internal group politics later caused the ACLU, the Communist Party, and other radical groups to change their positions, leading some to embrace the policies of the Roosevelt administration and others to adopt a neutral position. In July 1935, when Hitler and the Nazis were already a powerful force in Germany, the Seventh Congress of the Communist International announced the Party's strategy to combat world facism: Communists throughout the world were urged to join with socialists and other left-wing groups to form popular fronts against facism. ${ }^{180}$ Many radicals accepted the dictates of the Party and stifled their hostility towards Roosevelt and his New Deal policies. After July 1935, the Communists and other radical groups came to endorse the Wagner Act. ${ }^{181}$ World affairs, however, and not a recognition of the radical potential of this legislation, account for this ideological shift. ${ }^{182}$

The ACLU also changed its official position toward the Wagner Act in the spring of 1935.183 At a meeting in May 1935, "the ACLU board of directors voted . . . to rescind its "previous action opposing the bill' and authorized Baldwin to 'issue a public statement that the Union takes no position on it." "184 By early 1936, the ACLU had become an enthusiastic supporter of the Act and the

179 C. DANIEL, supra note 137, at 101 (quoting Letter from Harry F. Ward, Arthur Garfield Hays \& Roger N. Baldwin to Robert F. Wagner (April 1, 1935)).

180 See S. ARonowitz, supra note 137, at 241; C. Daniel, supra note 137, at 128-29; S. LENS, supra note 137, at 315. See generally F. WARREN, LmERALS AND COMMUNisM 103-17 (1966).

181 C. DANIEI, stupra note 137, at 129.

182 Howe and Coser present an alternative hypothesis to explain the Communist Party's policy change in 1935. They suggest it can plausibly be argued that changes in the character of the New Deal at about that time led liberals and radicals to approve of the newer, more leftist legislative programs. I. HowE \& L. Cosen, supra note 139, at 233-34. They then reject this hypothesis, however, arguing that the changes in policy were not marked enough to explain the change from denunciation prior to 1935 to uncritical acceptance thereafter. Id. 234. In addition, the Party's policy change occurred without discussion among the membership or in the group's publications. Id. These factors, according to Howe and Coser, demonstrate that the Party's change of position was in response to "Moscow needs." Id. 233-34.

183 C. DANIEr, supra note 137 , at 116-17.

184 Id. 117 (quoting Minutes of the Meeting of the ACLU Board of Directors (May 27, 1935)). 
NLRB. ${ }^{185}$ This policy reversal is best explained by two factors: the popular front movement ${ }^{186}$ and membership opposition to the ACLU leadership's positions. ${ }^{187}$ A 1935 ACLU membership referendum had made it clear that members did not support the board of directors' decision to oppose the Wagner Act. ${ }^{188}$ This internal dissension, marked by vocal criticisms aimed at Baldwin and others, ${ }^{189}$ contributed to the ACLU's policy reversal.

Although the ACLU, the Communist Party, and other radical groups 180 began to endorse the Roosevelt administration's policies by late 1935, Klare's characterization of the Wagner Act as "perhaps the most radical piece of legislation ever enacted by the United States Congress" 191 is not supported by the attitudes and beliefs of radical groups at the time. The sudden reversal of position by these radicals did not reflect a new understanding of the terms and implications of the Act that was more in line with their hopes for societal change. Instead, external events and organizational politics ${ }^{192}$ pressured the groups to adopt new policies. The terms and premises of the Act were never perceived to be radical by radical groups involved in the events of the period.

185 Id. 14-16, 127.

180 Id. 127-30; see text accompanying notes 180-82 supra.

187 See C. DANIEL, supra note 137, at 104-19.

188 Id. 107-12.

189 See id. 10407.

190 The Lovestoneites were not among those radical groups that changed their positions. Throughout the period 1935 to 1937, they continued to criticize the Roosevelt administration and its policies. See, e.g., Courts Rehearsing Wagner Act Ruling, Workers Age, Apr. 4, 1936, at 2, cols. 3, 4 (arguing that the creation of the NLRB would increase the power of "capitalist government" over the unions and thus bring them "under the direct rule of the bosses"); Brown, supra note 149, at col. 4 (urging the labor movement to denounce the Wagner Act).

191 Klare, supra note 3, at 265.

192 It appears that the ACLU leaders, Baldwin most importantly, did not embrace the change in the official ACLU position. See C. DANmeL, supra note 137, at 111, 118-19. It is possible to argue that the membership dissatisfaction with the ACLU's opposition to the Wagner Act provides some support for Klare's argument that working peoples' vision of the Act may have diverged substantially from that of the leaders of organized labor. See Klare, supra note 3, at 290. The members of the ACLU who provided the evidence of this dissatisfaction, however, were not common working people: in some cases, dissenting opinions were voiced by organization leaders or legal staff in ACLU regional branches, see C. DANxEx, supra note 137, at 110-1I, and other members attacking the leadership's policies were themselves union leaders, id. 38-44 (noting that Baldwin was criticized by socialist labor leader Morris Hillquit and by Joseph Schlossberg, the general secretary-treasurer of the Amalgamated Clothing Workers of America). Furthermore, the direction of this divergence is opposite to that suggested by Klare: it was the ACLU leadership, not the membership, that was more radical. 


\section{Conglusion}

Klare asserts that the Supreme Court rejected a possible interpretation of the Wagner Act that would have provided for collective bargaining in which the government's function was to scrutinize the substance of the wage bargain. By embracing a procedural review model, the Court, according to Klare, deradicalized the Act and reaffirmed the values most consistent with the capitalist order. Klare believes that, without substantive review by government, labor contracts will always pay the worker less than he produces, while placing him within a web of social relationships that limit his control over the production process. By choosing a collective bargaining model that kept issues regarding economic and social justice for workers out of public discussion, the Court, in Klare's view, depoliticized and deradicalized the labor movement.

Contrary to Klare's deradicalization argument, however, the Wagner Act did not embody radical ideals with respect to the government's role in regulating collective bargaining. The legislative history demonstrates that Congress did not intend the government to scrutinize the substance of the parties' private bargains. In addition, the speeches and writings of, legal scholars and the major interest groups working for and against the Wagner Act's passage indicate that there was a remarkable consensus against Klare's model of substantive review. For the Supreme Court to have interpreted section $8(5)$ as allowing or requiring government scrutiny of the terms of the wage offer would, in light of the legislative history and the popular mood, have constituted a radicalization of the Act.

This Comment has argued that the judicial decisions interpreting and applying the Wagner Act did not shape a new legal consciousness with respect to labor issues. Contrary to Klare's argument, the Supreme Court was not confronted with a variety of reasonable alternative interpretations of section $8(5)$ from which it chose the nonradical collective bargaining model. Rather, from the time it was proposed and enacted, the Wagner Act embodied only reformist ideals, and between 1937 and 1941 the courts and the NLRB worked to interpret and implement the Act consistently with them. 